\title{
Isolation and characterization of osmotolerant bacteria from Thar Desert of Western Rajasthan (India)
}

\author{
Ramavtar Sharma ${ }^{1}$, Rajni Manda ${ }^{1}$, Shikha Gupta ${ }^{1}$, Sushil Kumar ${ }^{1,2}$ \& Vinod Kumar ${ }^{3}$ \\ 1. Plant Biotechnology Centre, SK Rajasthan Agricultural University, Bikaner-334006, India; ras_rau@rediffmail.com \\ 2. Anand Agricultural University, Anand-388 110, India; sushil254386@yahoo.com \\ 3. NRC on Plant Biotechnology, Indian Agricultural Research Institute, New Delhi -110012; \\ veenu_yadav2003@rediffmail.com
}

Received 09-X-2012. C Corrected 24-III-2013. Accepted 24-IV-2013.

\begin{abstract}
The Thar Desert harsher environment harbors a limited diversity of life forms due to extreme conditions like low moisture of sandy soils and high soil temperature. In the present study, osmotolerant bacteria from the Thar soils were isolated and characterized. Bacteria were isolated from 20 soil samples (100g), collected from sand dunes, suspended in water and absolute alcohol. A total of 11 biochemical and morphological tests were carried out for generic identification of bacteria. Osmotic tolerance capacity of isolates was examined on glycerol, $\mathrm{NaCl}$ and alcohol; and sequencing of $16 \mathrm{~S}$ rRNA gene was also performed for bacterial identification. $16 \mathrm{~S}$ to $23 \mathrm{~S}$ rRNA internal transcribed spacer analysis (RISA) was done for phylogenetic analysis of isolates. The soil suspended in water contained $2.5 \times 10^{6} \mathrm{bacteria} / \mathrm{g}$ of soil while alcohol suspended soil had $4.4 \times 10^{4} \mathrm{bacteria} / \mathrm{g}$. The 24 bacterial isolates were found tolerant to $26 \%$ glycerol, $14 \% \mathrm{NaCl}$ and $10 \%$ of alcohol, and 22 out of 24 isolates were found Gram positive. The results showed that $45.83 \%$ and $41.67 \%$ bacteria belong to Bacillus spp. and Corynebacterium spp., respectively, while Acinetobacter spp., Aeromonas spp. and Staphylococcus spp. were in equal proportion (4.16\% each). Six isolates were selected for $16 \mathrm{~S}$ rRNA gene sequencing and five were found $95 \%$ similar with Bacillus licheniformis whereas one isolate was identified as $B$. subtilis. All the isolates showed good growth up to $50^{\circ} \mathrm{C}$ with gradual reduction on subsequent increment of temperature. Out of 24 isolates, six could survive at $65^{\circ} \mathrm{C}$ while one isolate could grow at $63^{\circ} \mathrm{C}$. Growth kinetic studies revealed that the reduction in generation time in solute(s) and temperature stress was more as compared to generation time in plain medium. This study suggests that virgin sand dunes may be a rich source of bacteria, tolerant to osmotrophic solutes, and can be examined for plant growth promotion activity in agriculture. Moreover, study might help to resolve the tactic adopted by microbes to defeat desiccation induced by various types of solutes. Rev. Biol. Trop. 61 (4): 1551-1562. Epub 2013 December 01.
\end{abstract}

Key words: bacteria, osmotolerant, RISA, temperature, Thar Desert.

The Thar Desert of North Western India is distributed over 2.34 million $\mathrm{km}^{2}$ with about 91\% area endemic to the Rajasthan. The low fertile sandy soil of this desert is poor in organic matter, having rapid water infiltration rates and rapid oxidation (Chowdhury, Michael, Anton \& Tripathi, 2007). Desert soil is an excellent ecosystem and colonized by various groups of microorganisms with extremities of environmental conditions. Soil microbial communities are among the most complex, diverse, and important assemblages in the biosphere (Zhou et al., 2003) and soil moisture is a key factor for microbial activity, its biomass and diversity in soils especially in desert (Kieft, 2002), and soil moisture stress leads to severe impact on vital metabolic processes and growth. To mitigate such stresses in desert, the bacteria must maintain osmotic equilibrium across the membrane by forming desiccationresistant spores or cysts (Gould \& Measures, 1977 ) or tolerating low water potential as vegetative cells (Busse \& Bottomley, 1989).

Kosmotropic (Glycerol) and chaotropic $(\mathrm{NaCl})$ salt ions are mostly used to create water stress which either disrupt or enhance hydrogen 
bonding networks (Collins \& Washabaugh, 1985; Cacace, Landau \& Ramsden, 1997). High levels of extracellular solutes such as $\mathrm{NaCl}$ reduce cell turgor which induce osmotic stress, leading to membrane rigidity and impairment of protein structure (Hallsworth, Prior, Nomura, Iwahara \& Timmis, 2003). Non-ion-chaotropic compounds viz. ethanol, phenol, urea that weaken electrostatic interactions in biological macromolecules, can reduce intracellular water availability without having a major impact on cell turgor. Ethanol caused intracellular non-stressed water stress due to alterations in the hydration of cellular macromolecules (Hallsworth et al., 2003).

Desert harbour a plethora of extremophiles ranging from halophiles, halotolerant, thermotolerant to radiation tolerant types but their knowledge is still limited to explore their potential. Most studies were conducted in specific niches or habitats, and large part of it still remains to be explored. Therefore, understanding the extent of microbial diversity is still incomplete. More studies on a variety of soil types and habitats are needed to obtain a comprehensive view of microbial community composition and structure in soil environments. Isolation and studies of osmotolerant microbes from desert have been restricted to halotolerant types. In addition to the inherent importance of gaining an understanding of water stress in biological systems, this study may find out novel bacteria that can be used further for gene isolation. The potential of microbes to tolerant non-ionic solutes is yet not reported. Plenty of methods are available to explore microbial identity and as 16S rRNA gene sequence analysis is prevalent in this regard. However, sometimes it fails in distinguishing between closely related organisms. Focus on the $16 \mathrm{~S}$ to 23S rRNA internal transcribed spacer analysis (RISA) has increased (Herry, Hichem \& Noureddine, 2009). To better understand the extent of microbial diversity in soil, we used the biochemical and 16s rRNA/ RISA approach to analyze microbial community structure of sandy surface soil from Thar. Thus, present investigation sought to determine whether bacteria present in the Thar Desert that are naturally subjected to desiccation and salts concentrating around soil particles during soil drying, are tolerant to Kosmotropic (Glycerol) and chaotropic $(\mathrm{NaCl})$ and Non-ion-chaotropic (ethanol) solutes. In this study, we used RISA and 16S rRNA gene sequencing of extremophilic bacteria from the Thar Desert, screened on water stress causing medium. The selected strains were also characterized for morphological and biochemical parameters.

\section{MATERIALS AND METHODS}

Sample collection: For bacterial isolation, soil samples (100g) from three (Bikaner, Gajner and Deshnoke) places -about $35 \mathrm{~km}$ away from each other- were collected from upper surface and at a depth of about $10-15 \mathrm{~cm}$ in sterile polythene bags from Thar Desert of Bikaner region of Western Rajasthan (geographical coordinates, $28^{\circ} 01^{\prime} 00^{\prime \prime} \mathrm{N}-73^{\circ} 18^{\prime} 43^{\prime \prime}$ E). The samples in bags were immediately transported to the laboratory aseptically. This area experiences erratic annual rainfall (100$500 \mathrm{~mm}$ ), wide variations in diurnal soil temperatures $\left(28-60^{\circ} \mathrm{C}\right)$ in summer, low relative humidity (30-80\%) and high evapo-transpiration (1600-1800mm). Low fertile calcareous and sodic soils are predominately light textured and weak structured. For isolation of bacteria, soils were mixed and sieved through $2 \mathrm{~mm}$ mesh screen after removing visible debris and stored at $-80^{\circ} \mathrm{C}$.

Isolation and purification of microorganisms: One gram of soil sample was suspended and mixed $(5 \mathrm{~min})$ in $99 \mathrm{~mL}$ sterile distilled water as well as in $100 \mathrm{~mL}$ of absolute alcohol and left for one hour, followed by inoculation of $100 \mu \mathrm{L}$ of suspension on plain $1.5 \%$ nutrient agar medium containing three different screening media i.e. PEG 6000 (glycerol) medium $(0,15,18,21$ and $25 \%), \mathrm{NaCl}$ medium $(0,2,4,8$ and $12 \%)$ and alcohol medium $(0,2$ to $5 \%$ ) and incubated at 37,45 and $50^{\circ} \mathrm{C}$. After $24 \mathrm{~h}$, single bacterial colonies were picked and further sub-cultured several times to obtain pure 
cultures. Individual (a total of 79) colonies of bacteria which varied in shape and color, were picked up and purified by streaking on nutrient agar. The colonies were transferred to nutrient slants for different tests. The bacterial communities were examined using a combination of culturing and culture-independent methods.

Morphological and biochemical characterization: The bacterial isolates were identified on the basis of classification schemes published in Bergey's Manual of Systematic Bacteriology (Krieg \& Holt, 1984). The isolates examined for morphology, Gram staining, motility, growth in air, acid fastness, spore formation and biochemical characterization (catalase activity, oxidase activity, oxidation-fermentation test, glucose fermentation test and lactose fermentation test) (Kandler \& Weiss, 1986).

Osmotic potential tolerance in combination with temperature: Osmotic tolerance capacity of isolates was examined on high concentration of glycerol $(18,20,22,24,26$ and $28 \%), \mathrm{NaCl}(10$ to $15 \%)$ and alcohol (6 to $11 \%$ ) in combination with two temperature regimes $\left(45^{\circ} \mathrm{C}\right.$ and $\left.50^{\circ} \mathrm{C}\right)$. The growth data on colonies were collected on visual basis after 24h. Growth curves for most tolerant isolates were constructed on different screening media to study the growth pattern at different temperatures $\left(40,50\right.$ and $\left.60^{\circ} \mathrm{C}\right)$. Optimal density at $\mathrm{OD}_{600}$ based graph of growth was drawn at $30 \mathrm{~min}$ interval for $12 \mathrm{~h}$. All these isolates were also tested for halotolerance/halophilic nature in modified medium lacking $\mathrm{NaCl}$. Similarly, to examine the temperature tolerance capacity of isolates in the absence of chemical (glycerol, $\mathrm{NaCl}$ and alcohol) stress, 24h old culture was streaked on plain agar medium and incubated on five different temperature regimes $(37,45$, 55,60 and $65^{\circ} \mathrm{C}$ ), and examined for differential growth density afterwards.

PCR amplification of 16S rRNA gene and 16S-23S rRNA intergenic spacer: For the culture-independent methods, plasmid and genomic DNA were isolated from 24 isolates and purified using the method of Sambrook \& Russell (2001). The 16S rRNA gene amplification was carried out in $25 \mu \mathrm{L}$ reaction mixture containing $1 \mathrm{X}$ reaction buffer, $200 \mu \mathrm{M}$ dNTPs, $10 \mathrm{pm}$ of each oligonucleotide primers $(27 \mathrm{~F}$ 5'AGAGTTTGATCCTGATCCTGGCTCAG 3'/1492R-5'TACCTTGTTACGACTT3'), Taq DNA polymerase (1U, Bangalore Genei Pvt. Ltd., India) and 50ng template DNA in thermal cycler (Model-CGI-96, Corbett Research, Australia). The PCR reaction was performed in 35 cycles: one cycle of denaturation at $94^{\circ} \mathrm{C}$ for $5 \mathrm{~min}$ followed by 34 cycles of denaturation at $94^{\circ} \mathrm{C}$ for $1 \mathrm{~min}$, annealing at $60^{\circ} \mathrm{C}$ for $1 \mathrm{~min}$ and extension at $72^{\circ} \mathrm{C}$ for $1 \mathrm{~min}$ and final extension at $72^{\circ} \mathrm{C}$ for $7 \mathrm{~min}$. For RISA the same PCR methodology was followed except primer pairs (ITS-72-F 5'CCGGCTTTCCCCATTCGG3' ITS-38-R 5'TGCGGCTGGATCTCCTT3'). The PCR products were mixed with 10X DNA loading buffer and separated on $1.2 \%$ agarose gel containing $0.5 \mu \mathrm{g} / \mathrm{mL}$ of ethidium bromide and visualized under UV trans-illuminator. The sequences of 16s rRNA gene for six selected isolates were obtained from Banglore Genei, Banglore (India) through their custom services by submitting the PCR product. Resulting sequences were compared to a local database collection and to GenBank sequences (BLAST search) to attain species identities. For RISA, amplicons were scored for the presence (1) or absence (0) as binary codes, and imported in NTSYS program v 2.02 (Rohlf, 1998) to calculate Jaccard's similarity coefficients. Unweighted pair group method with arithmetic mean (UPGMA) was used for cluster analysis.

\section{RESULTS}

Isolation of stress tolerant bacterial isolates: Without any chemical stress (control), water suspended soil samples (WS3) incubated at $37^{\circ} \mathrm{C}$ and $50^{\circ} \mathrm{C}$ contained $2.5 \times 10^{6}$ and $1.1 \times 10^{5}$ bacteria/g dry soil, respectively. Hence, the bacterial count decreased 20 times with increase in incubation temperature from 37 to $45^{\circ} \mathrm{C}$, while growth was unaffected on further rise in temperature up to $50^{\circ} \mathrm{C}$. 
Bacterial population reduced 55 times in alcohol suspended soil samples (AS3) at $37^{\circ} \mathrm{C}$ as compared to water suspension. The bacterial population of AS3 ranged from $4.4 \times 10^{4}$ to $9.0 \times 10^{3} / \mathrm{g}$ of dry soil and bacterial count reduced 1.02 times when temperature rised from 37 to $45^{\circ} \mathrm{C}$, while a drastic reduction was observed (4.7 times) at $50^{\circ} \mathrm{C}$. Bacterial population decreased with the increasing concentration of chemicals (alcohol, glycerol and $\mathrm{NaCl}$ ) in nutrient medium at various temperatures; thus, both stresses simultaneously caused a detrimental effect on population growth. With AS3, no colonies were detected at extremities of incubation temperature and chemical(s) concentration. Sporulating bacteria were avoided from WS3 by picking colonies that could survive at maximum temperature and chemical concentration. Eventually, 79 diverse and tolerant colonies (16 on $12 \% \mathrm{NaCl} ; 28$ on $25 \%$ glycerol and 35 on 5\% alcohol) were selected and tested for their viability in respective higher concentration of $\mathrm{NaCl}(15 \%)$, glycerol $(30 \%)$ and alcohol (10\%). Respectively, 6 (37.5\%), 7 (25\%) and 11(31.4\%) colonies (a total 24 ) survived on $15 \% \mathrm{NaCl}, 30 \%$ glycerol and $10 \%$ alcohol.

Characterization of isolates based on primary identification: In staining test, 22 out of 24 selected isolates were Gram positive. Motility was observed in 16 isolates, and all were aerobic in nature as they grow in air. All isolates were negative in acid fast reaction which indicates the absence of mycolic acids, mycosides, wax and bound lipids in cell wall. Morphologically, rod shaped bacteria showed predominance as only single isolate was of spherical (cocci) shaped. Out of 24, 19 isolates were detected as non-sporulating blue cells, and none of the two Gram negative bacteria was sporulating. All isolates were found positive for oxidase reaction, but eight isolates showed fast reaction by production of more effervescence within few seconds. Oxidase test was positive in 12 isolates with appearance of purple colour while five isolates developed dense purple colour. This result showed the presence of cytochrome $\mathrm{C}$ oxidase in these isolates. All isolates were found negative on MacConkey agar medium, HL medium and glucose fermentation tests.

Above performed generic identification tests classified bacterial isolates into five different genera (Table 1). The results showed that $45.83 \%$ bacteria belong to Bacillus spp., $41.67 \%$ Corynebacterium spp. and rest equally (4.16\% each) to three species of Acinetobacter spp., Aeromonas spp. and Staphylococcus spp. Concisely, Bacillus spp. was in greater abundance among stress tolerant bacteria.

Effect of various solutes in combination with temperature: The present results specify that bacterial isolates from desert have potential to grow well in various concentrations of solutes. Most of isolates could grow on all temperatures $\left(40,50\right.$ and $\left.60^{\circ} \mathrm{C}\right)$ though most efficient growth was recorded at $50^{\circ} \mathrm{C}$ in the absence of chemical (alcohol, $\mathrm{NaCl} \&$ PEG) stresses. All the isolates grew efficiently on $\mathrm{NaCl}$ free medium which also indicated that isolates were halotolerant in nature not halophilic (salt loving). Though, the tolerance for osmotic-and temperature-stress was significant for most strains. But, some of the isolates exhibited growth as high as on $14 \% \mathrm{NaCl}, 10 \%$ alcohol and $26 \%$ glycerol at $45^{\circ} \mathrm{C}$. However, detrimental effect of higher temperature $\left(50^{\circ} \mathrm{C}\right)$ was evident even at lower solute concentration.

Bacterial isolates were tested for their capability to stand higher temperatures ( 37 , $45,50,55,60,63$ and $65^{\circ} \mathrm{C}$ ) in the absence of chemical stress. All the isolates showed good growth up to $50^{\circ} \mathrm{C}$ with gradual reduction on subsequent increment of temperature. Six isolates (M2, M4, S1, S2, S3 and S4) could survive at $65^{\circ} \mathrm{C}$, while one isolate (R4) could grow at $63^{\circ} \mathrm{C}$. Optimum growth temperature of $\mathrm{S} 4 / \mathrm{R} 4$ and $\mathrm{M} 2$ was detected at $40^{\circ} \mathrm{C}$ and $50^{\circ} \mathrm{C}$, respectively, which resulted higher than control temperature $\left(37^{\circ} \mathrm{C}\right)$. However, higher temperature $\left(60^{\circ} \mathrm{C}\right)$ was detrimental to growth but even though bacteria maintain very subdued growth. Bacterial growth entered in stationary phase after 11h (S4 and R4) and 12h (M2). 


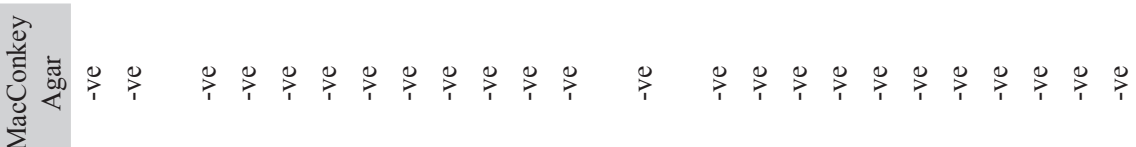

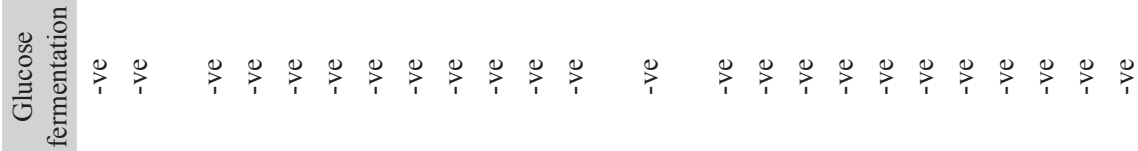

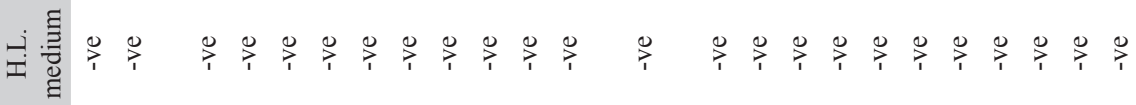

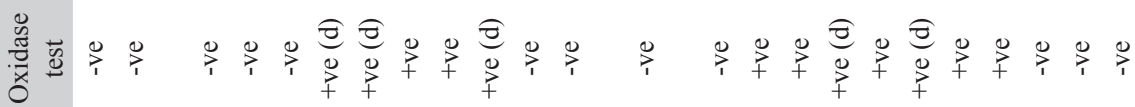

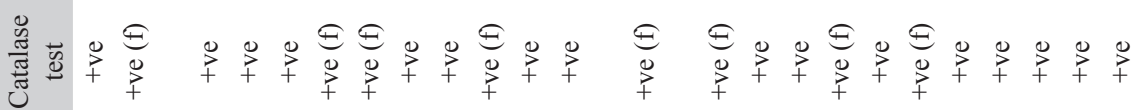

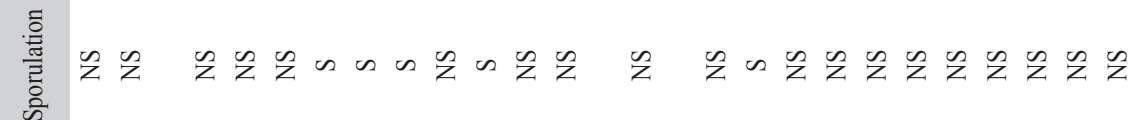

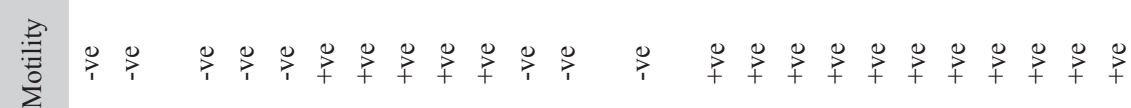

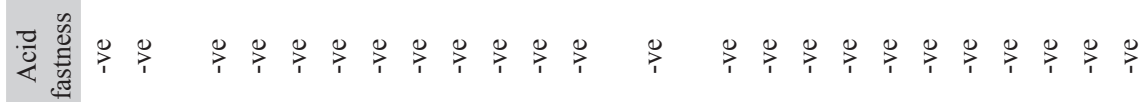

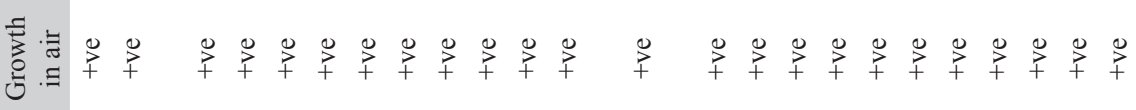

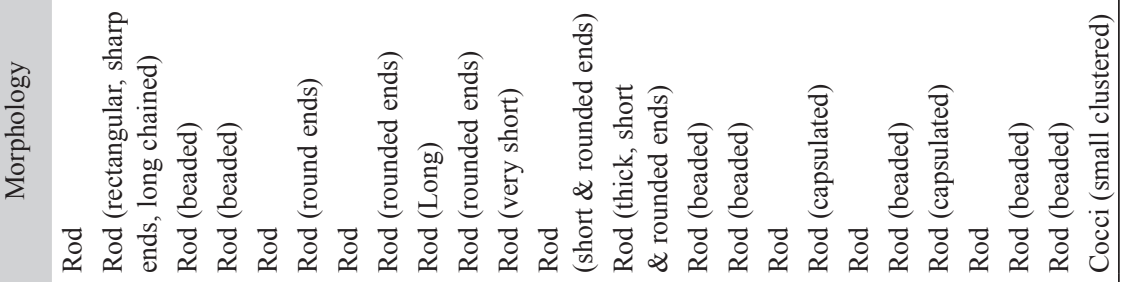

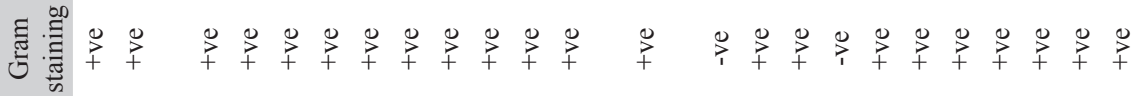

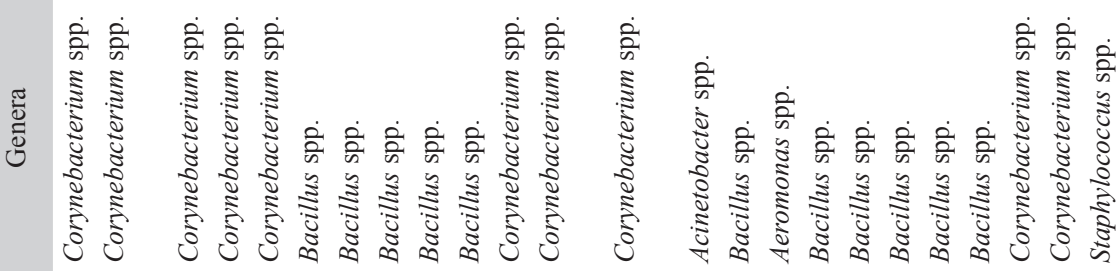

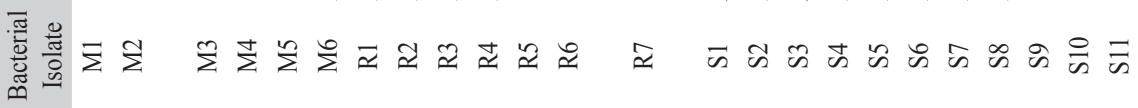

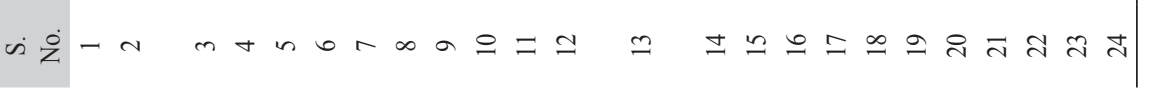


Growth kinetics of isolate $\mathrm{M} 2$ on $\mathrm{NaCl}$ $(0,7$ and $14 \%), \mathrm{R} 4$ on glycerol $(0,15$ and $25 \%)$ and $\mathrm{S} 4$ on alcohol $(0,4$ and $8 \%)$ was calculated to determine the effect of respective solute in combination with three temperature regimes $\left(40,50\right.$ and $\left.60^{\circ} \mathrm{C}\right)$. The results showed growth suppression effect of higher concentration of solutes on respective isolates (Fig. 1). The bacterial growth inhibited at extremes of chemical concentration. While, $15 \%$ glycerol and $4 \%$ alcohol delayed lag phase for $4 \mathrm{~h}$ as against $1.5 \mathrm{~h}$ on control medium. Compared to both solutes, $7 \% \mathrm{NaCl}$ delayed lag phase for $5 \mathrm{~h}$ when compared to $2.5 \mathrm{~h}$ on control medium. Exceptionally, S4 isolate in control condition at $60^{\circ} \mathrm{C}$ showed abrupt increase in cellular growth in log phase, with subsequent sudden drop in cell mass.

Ribotyping: Two most tolerant isolates (M1 \& M4; R2 \& R4; S4 \& S5) from each screening groups were selected for cloning and sequencing of a single fragment of nearly 800bp (16S rRNA gene) to compare sequence similarity. The Blastn of sequences for isolate M1, M4, R2, S4 and S5 declared a 95\% similarity with Bacillus licheniformis (accession number EF635428), whereas isolate R4 was identified as $B$. subtilis and its nearest homolog species was found to be $B$. amyloliquefaciens (Accession No. EF423605). Absence of plasmid in all isolates indicated the presence of stress tolerant genes on genomic DNA.

Electrophoresis and fragment size analysis of RISA products revealed extensive variability in the number and size of spacer regions and resulted in 14 distinct band patterns with a total of 10 fragments ranged from 100 to $600 \mathrm{bp}$ (Fig. 2). The isolates M1 to M5 had identical banding pattern while M6 differed from rest of isolates selected from salt tolerant bacteria.
A

Growth curve $\left(40^{\circ} \mathrm{C}\right)$

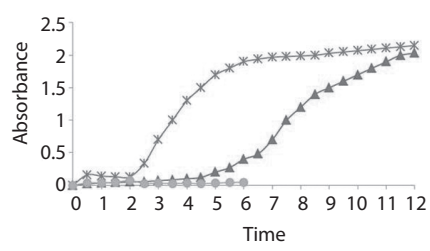

Growth curve $\left(50^{\circ} \mathrm{C}\right)$

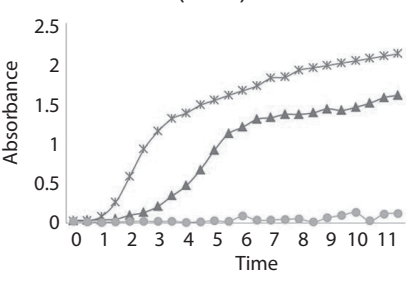

Growth curve $\left(60^{\circ} \mathrm{C}\right)$
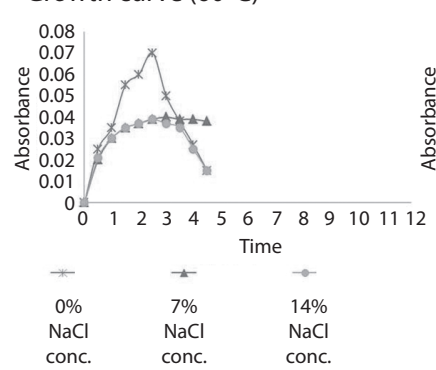

B

Growth curve $\left(40^{\circ} \mathrm{C}\right)$

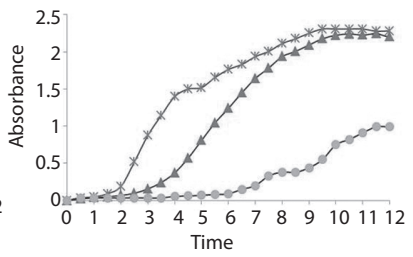

Growth curve $\left(50^{\circ} \mathrm{C}\right)$

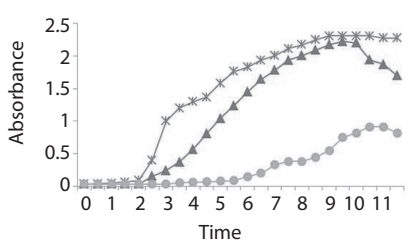

Growth curve $\left(60^{\circ} \mathrm{C}\right)$

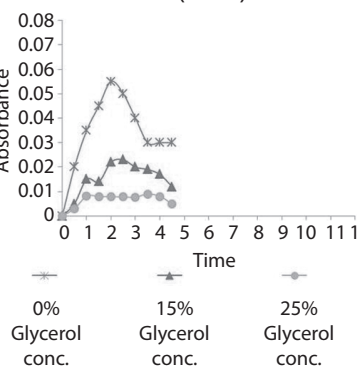

C

Growth curve $\left(40^{\circ} \mathrm{C}\right)$

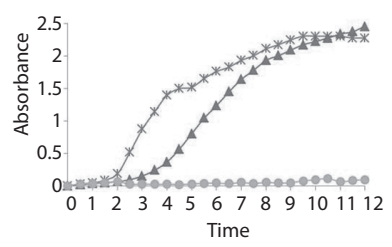

Growth curve $\left(50^{\circ} \mathrm{C}\right)$

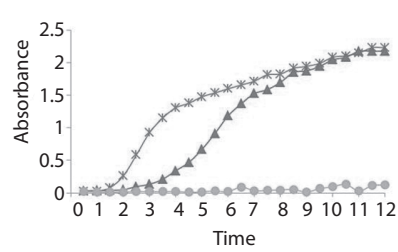

Growth curve $\left(60^{\circ} \mathrm{C}\right)$

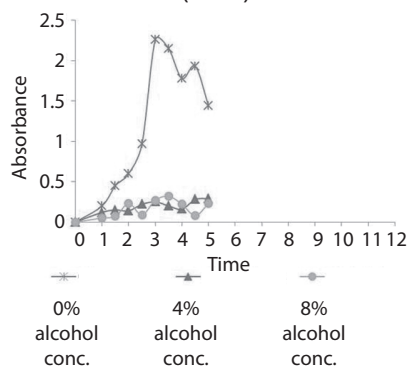

Fig. 1. Growth Curve of isolate A) $\mathrm{M} 2$ on $\mathrm{NaCl}(0,7$ and 14\%) B) $\mathrm{R} 4$ on glycerol (0, 15 and 25\%) and C) $\mathrm{S} 4$ on alcohol $(0,4$ and $8 \%)$ at different temperatures. 


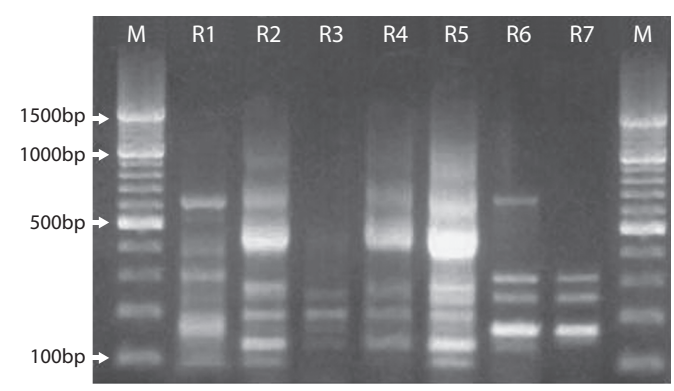

Fig. 2. RISA profiles of seven bacterial population generated using ITS-72-F/ITS-38-R primer; M-100bp DNA ladder

Similarly, the two isolates identified as Cornybacterium (S9 and S10) were also completely similar. Jaccard's similarity coefficients for 24 isolates were ranged from zero to one with an average similarity of 0.45 , and revealed $100 \%$ dissimilarity between isolate S11 (Staphylococcus spp.) and 11 other isolates. UPGMA-based clustering generated three major clusters in which cluster $3^{\text {rd }}$ was grouped with two isolates (S11 \& M11) at similarity coefficient of 0.26 . Cluster 1 was grouped with maximum number (19) of isolates. Most of the samples showed very higher similarity which might be due to less number of amplicons from RISA. Cluster one was consisting four sub-clusters in which all $\mathrm{NaCl}$ tolerant isolates (all Corynebacterium) clubbed together except isolate M6 (Bacillus), that grouped in cluster $3^{\text {rd }}$. Out of 11 glycerol tolerant isolates, ten were grouped in cluster one while isolate S11 was collapsed in cluster $3^{\text {rd }}$ (Fig. 3).

\section{DISCUSSION}

The osmotic stress is an important physical parameter that influences the ability of microbes to grow, proliferate and successfully compete for given habitat (Kempf \& Bremer, 1998). The present research tested the survival of bacterial isolates of desert soil under osmotic and drought stress conditions. The culture based method was used to screen bacteria under osmotic stress conditions and finally characterized and compared through culture- and DNA-based results. In present investigation the bacterial population in control was little higher than earlier reported for Thar (Venkateswarulu \& Rao, 1981; Khathuria, 1998). However, the bacterial population reduced to 20 times at higher temperature but a considerable population showed thermotolerance bacterium. The thermo-tolerance bacteria from desert have been isolated by various researchers (El-Nawawy,1992; Khyami-Horni,

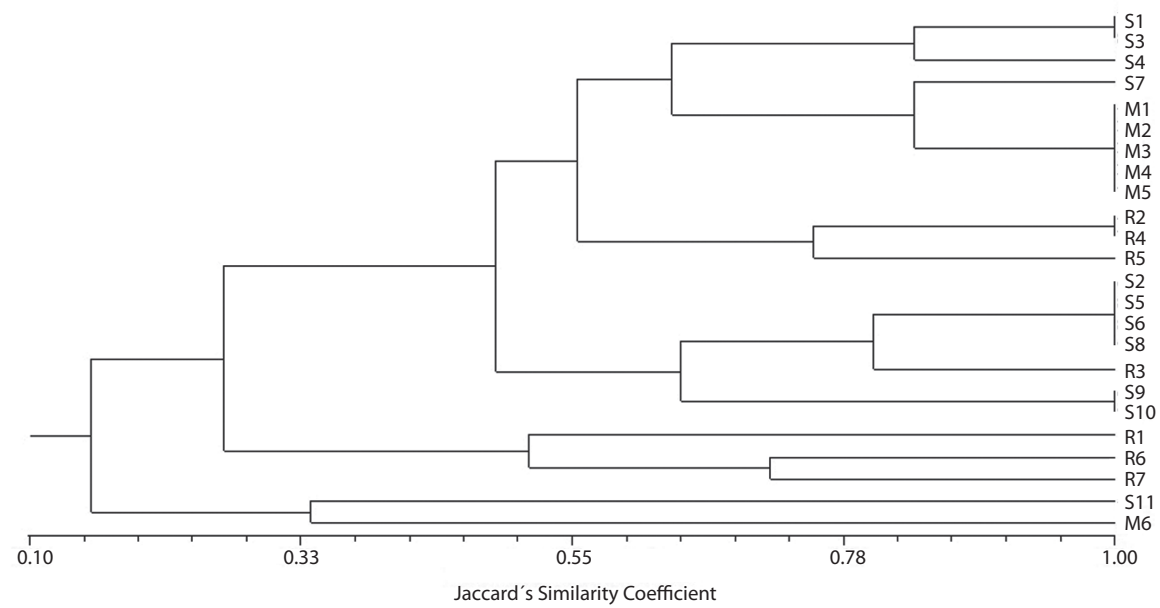

Fig. 3. UPGMA based Jaccard's similarity dendrogram among 24 osmotolerant soil bacteria on the basis of 16S-23S rRNA ribotyping. 
1996), and indicated that the composition and diversity of soil bacterial communities can be influenced by a wide range of abiotic factors (Buckley \& Schmidt, 2002), and soil moisture is one of them which can directly affect the physiological status of bacteria (Harris, 1981). So far, no study has been reported on growth kinetics of bacteria prevalent in the Thar Desert under various levels of moisture stresses. Bacterial growth retarder proportionally to increasing concentration of stress causing agents but few obviated the stress and increased their population suggesting the presence of osmotic tolerant bacteria in Thar soil, which is expected to be under low osmotic pressure generated due to matric potential. This could be explained on the basis of the observations of Hallsworth et al. (2003) who indicated the involvement of general dessication tolerance mechanism against water stress.

In addition to water, the soil was also suspended in absolute alcohol to determine the survival of bacterial spores in alcohol. Results not only indicated the decrease in bacterial population by 50 times at $37^{\circ} \mathrm{C}$, but also revealed the presence of sporulating bacteria in soil, as spores can tolerate high degree of osmotic potential, temperature and irradiation. However, none of these sporulating bacteria could grow on medium with $5 \%$ alcohol (at $50^{\circ} \mathrm{C}$ temperature), $8 \% \mathrm{NaCl}$ (at $50^{\circ} \mathrm{C}$ temperature) and glycerol above $15 \%$ (at $45^{\circ} \mathrm{C}$ and above temperature). Therefore, we selected the colonies from water suspended soil in order to devoid non-sporulating bacteria for further study.

The study revealed the abundance of Gram positive bacteria $(91.6 \%)$ in soil which had been reported earlier (Rao \& Venkateswarulu, 1983; Rainey et al., 2005). Similarly, the proportion of Gram positive bacteria in grassland (Felske, Wolterink, Lis \& Akkermans, 1998) and forest soil (Borneman \& Triplett, 1997) was also reported in much higher amount. Gram-positive bacteria along with thicker and rigid cell wall also possess intracellular compatible solutes that help in better osmoregulatory capabilities (Arshad, Shafqat \&
Farooq-E-Azam, 2006); consequently bacteria can survive under extreme water scarcity. All the isolates were aerobics and this result was in line with Glavin, Cleaves, Schubert, Aubrey \& Bada (2004) where they also found soils rich in aerobic bacteria. In present study, bacteria were deliberately chosen to avoid sporulating ones even though five isolates were found sporulating. Rao \& Venkateswarulu (1983) and Busse \& Bottomley (1989) also reported that soil bacteria can sustain under water stress without forming spores. All the isolates in the study showed catalase activity. However, eight isolates showed higher catalase activity which is proportional to tolerance capacity of bacteria and also indicates the role of catalase in survival of bacteria under stress. The mechanism of quenching the free radicals generated under various stresses by catalase (Pomposiello \& Demple, 2002) support the present finding.

Bacillus and Corynebacterium were predominating in the investigated soil, along with other bacteria that include Staphylococcus, which is in agreement with previous reports (Brown, 1990; Bhatnagar \& Bhatnagar, 2005). Gupta \& Sharma (2011) also detected the Bacillus in all soil samples in arid region similar to present study. Bacillus sp. has been identified as plant-growth-promoting rhizobacteria, hence can be exploited in desert for crop production increment. Members of the genus Staphylococcus are human pathogens and infrequent in soil, but some species have been isolated from the rhizosphere of wheat, potato, and strawberry, suggesting their opportunistic mode of existence (Berg, Leo \& Anton, 2005).

The results revealed that thermo-tolerance capacity of bacterium was higher in stress free nutrient medium as survival was recorded up to $65^{\circ} \mathrm{C}$. These results are in line with Jadhav, Salunkhe, Nerkar \& Bhadekar (2010). Thermo-tolerant bacterial populations identified in solute stress free conditions are important for desert environments, where higher soil temperature devoid the solute stress. According to Kushner (1998), halotolerant bacteria are able to grow in absence as well in presence of high salt concentration. The halotolerant rather than 
halophilic nature of isolates investigated in present study was indicated by their growth on nutrient medium without $\mathrm{NaCl}$. Thus the desert soils, that normally experience matric potential, are full of halotolerant, thermo-tolerant and osmotolerant bacteria indicate the similar tolerance mechanism.

A sequencing dependent approach can provide a semi-quantitative estimate of the relative abundance of different groups of bacteria within a community, whereas culturing reveals the organisms that are viable, and provides appropriate organisms for investigations of bacterial adaptation to various stresses (Aislabie et al., 2006). B. licheniformis was identified as a major group among five selected isolates where only one isolate blasted with B. subtilis. Bacteria of the genus Bacillus are among the most widespread micro-organisms in nature. Such dominance is highly rare for surface soils (Zhou et al., 2003; Aislabie et al., 2006) but may be a feature of desert ecosystem. Previously, also, such dominance of bacterial ribotypes sequences were detected in soil. Zhou et al. (2003) proposed that dominance of particular bacterial strain in soils may be due to more competitive to use available resources and are better adaptation to the Thar ecosystem conditions. Stress tolerant ability of the present set of isolates was found to be associated with genomic DNA as plasmid was absent in all isolates. Two isolates (M1 \& M4) were phenotypically identified as Corynebacterium but later categorized as B. licheniformis in rRNA sequence. This is, however, astonishing, as the Corynebacterium is non-sporulating while $B$. licheniformis is sporulating type bacteria. Though, non-sporulating $B$. licheniformis have not been reported to be found in nature, but a number of non-sporulating strains have been produced in laboratory (Nahrstedt et al., 2005). Indeed, Otsuka, Suda, Li, Matsumoto \& Watanabe (2000) reported that morphological criteria are frequently variable, and depend on the environment. Moreover, a single indel mutation in gene is sufficient to convert non-sporulating types. Appearance of non-sporulating
B. licheniformis may be attributed to the isolation procedure of bacteria under stress. An abundance of fast-arranged genetic variations together with genetic adaptations in bacteria can resist environmental stresses like heat and water stress. Furthermore, Natural transformation has been shown to occur in soil and has been detected in more than 40 bacterial species (Nielsen et al., 1997). Bacteria, like B. subtilis and Acinetobacter calcoaceticus, can take up DNA fragments independent of their sequence (Lorenz \& Wackernagel, 1994). Thus, horizontal gene transfer (Klotz \& Loewen, 2003) coupled with limited resolution power due to highly conserved 16S rRNA gene sequence, might also confound the expected results.

Length polymorphism analysis of amplified ITS regions by RISA has been used as an efficient tool for species differentiation by several authors (Pangallo et al., 2009). RISA has differentiated the bacteria into five types, however, strains selected from $\mathrm{NaCl}$ showed $100 \%$ similarity. The length and number of the 16S-23S rRNA intergenic spacer has been found to be highly variable in strains screened through glycerol.

In summary, the present study revealed bacterial strains which can sustain a great level of osmotic stresses and their biochemical and molecular characterization entails diverse bacterial strains. Water and temperature stress resisting abilities of the bacterial strains from the Thar Desert soil proposes the further extension of the study at broad spectrum in finding more variable and highly resisting strains. However, the study considered only non-rhizospheric bacterial strains but their high stress tolerant abilities can be harnessed for betterment of dryland agriculture which needs identification, cloning and functional characterization of genes in such bacteria that confer resistance towards stresses. Moreover, these bacteria can be examined for plant growth promotion in agriculture. Understanding of bacterial diversity can be used to assess potential effects of desert farming on soil ecosystem services like plant health. 


\section{ACKNOWLEDGMENT}

We are duly acknowledged to A.K. Kataria, Assistant Professor, (Veterinary Microbiology) RAJUVAS, Rajasthan for his help in biochemical characterization of isolates.

\section{RESUMEN}

El duro ambiente del desierto de Thar alberga una diversidad de formas de vida limitado debido a sus condiciones extremas, como el bajo contenido de humedad de los suelos arenosos y la alta temperatura del suelo. En el presente estudio, las bacterias osmotolerantes de los suelos de Thar, fueron aislados y caracterizados. Las bacterias fueron aisladas a partir de 20 muestras de suelo $(100 \mathrm{~g})$, obtenidas de dunas de arena, suspendidas en agua y alcohol absoluto. Un total de 11 pruebas bioquímicas y morfológicas se llevaron a cabo para identificar géneros de bacterias: la capacidad de tolerancia osmótica de los aislados se examinó con glicerol, $\mathrm{NaCl}$ y alcohol, y la secuenciación de los genes $16 \mathrm{~S}$ rRNA se realizó también para la identificación bacteriana. El análisis de espaciadores internos transcritos de $16 \mathrm{~S}$ a $23 \mathrm{~S}$ rRNA (RISA) se realizó para los aislamientos de análisis filogenéticos. El suelo suspendido en el agua contuvo $2.5 \times 10^{6}$ bacteria/g de suelo mientras que el suelo con alcohol suspendido presentó $4.4 \times 104$ bacteria/g. Los 24 aislados bacterianos se encontraron tolerantes a $26 \%$ glicerol, $14 \% \mathrm{NaCl}$ y $10 \%$ de alcohol y 22 de los 24 aislados fueron grampositivas. Los resultados mostraron que $45.83 \%$ y $41.67 \%$ de las bacterias son Bacillus spp. y Corynebacterium spp., respectivamente, mientras que Acinetobacter spp., Aeromonas spp. y Staphylococcus spp. se presentaron en la misma proporción ( $4.16 \%$ cada uno). Seis aislamientos fueron seleccionados para secuenciación de genes 16S rRNA y 95\% fueron similares a Bacillus licheniformis mientras que un aislamiento fue identificado como B. subtilis. Todos los aislamientos mostraron un buen crecimiento a $50^{\circ} \mathrm{C}$ con reducción gradual en el incremento subsiguiente de la temperatura. Fuera de 24 aislados, 6 podrían sobrevivir a $65^{\circ} \mathrm{C}$ mientras que un aislado podría crecer a $63^{\circ} \mathrm{C}$. Estudios de crecimiento cinéticos revelaron que la reducción en el tiempo de generación en soluto (s) y estrés de temperatura fue mayor en comparación con el tiempo de generación en un medio simple. Este estudio sugiere que las dunas de arena virgen pueden ser una fuente rica de bacterias, tolerantes a los solutos osmotróficos y se pueden examinar para la promoción de crecimiento de plantas en la agricultura. Por otra parte, el estudio podría ayudar a resolver la táctica adoptada por los microorganismos para rechazar la desecación inducida por diversos tipos de solutos.

Palabras clave: bacterias, osmotolerante, RISA, temperatura, Desierto de Thar.

\section{REFERENCES}

Aislabie, J., Chhour, K., Saul, D. J., Miyauchi, S., Ayton, J., Paetzold, R. F. \& Balks, M. R. (2006). Dominant bacterial groups in soils of Marble Point and Wright Valley, Victoria Land, Antarctica. Soil Biology and Biochemistry, 38, 3041-3056. doi:10.1016/j. soilbio.2006.02.018

Arshad, R., Shafqat, F. Farooq-E-Azam. (2006). Rhizospheric bacterial diversity: is it partly responsible for water deficiency tolerance in wheat? Pakistan Journal of Botany, 38(5), 1751-1758. Retrieved from www.pakbs.org/pjbot/PDFs/38(5)/PJB38(5)1751.pdf

Berg, G., Leo, E. \& Anton, H. (2005). The rhizosphere as a reservoir for opportunistic human pathogenic bacteria. Environmental Microbiology, 7(11), 1673-1685. doi: 10.1111/j.1462-2920.2005.00891.x

Bhatnagar, A. \& Bhatnagar, M. (2005). Microbial diversity in desert ecosystem. Current Science, 89(1), 91-100. Retrieved from http://www.iisc.ernet.in/currsci/ jul102005/91.pdf

Borneman, J. \& Triplett, E. W. (1997). Molecular microbial diversity in soils from eastern Amazonia: evidence for unusual microorganisms and microbial population shifts associated with deforestation. Applied and Environmental Microbiology, 63, 2647-2653. Retrieved from http://aem.asm.org/content/63/7/2647.full.pdf + html.

Brown, E. (1990). Other Corynebacteria. In G. L. Mandell, R. G. Douglas \& J. E. Jr. Benett (Ed.), Principles and Practice of Infectious Diseases. New York: Churchill Livingstone, Inc.

Buckley, D. \& Schmidt, T. (2002). Exploring the biodiversity of soil - A microbial rain forest. In Staley, J. \& Reysenbach, A. (Ed.), Biodiversity of Microbial Life (p.p. 183-208). New York: John Wiley \& Sons.

Busse, M. D. \& Bottomley, P. J. (1989). Growth and nodulation responses of Rhizobium meliloti to water stress induced by permeating and nonpermeating solutes. Applied and Environmental Microbiology, 55, 2431-2436. Retrieved from http://aem.asm.org/ content/55/10/2431.full.pdf + html

Cacace, M. G., Landau, E. M. \& Ramsden, J. J. (1997). The Hofmeister series: salt and solvent effects on interfacial phenomena. Quarterly Reviews of Biophysics, 30, 241-277. doi:10.1017/S0033583597003363

Chowdhury, S. P., Michael, S., Anton, H. \& Tripathi, A. K. (2007). Identification of Diazotrophs in the Culturable Bacterial Community Associated with Roots of Lasiurus sindicus, a Perennial Grass of Thar Desert, India. Microbial Ecology, 54, 82-90. doi:10.1007/ s00248-006-9174-1

Collins, K. D. \& Washabaugh, M. W. (1985). The Hofmeister effect and the behavior of water at interfaces. 
Quarterly Reviews of Biophysics, 18, 323-422. doi: 10.1017/S0033583500005369

El-Nawawy (1992). Microbial Biomass Production from Organic Solid Substrates. In H. W. Doelle, D. A. Mitchell \& C. E. Rolz (Ed.), Solid Substrate Cultivation (pp. 247-268). London: Elsevier Applied Science.

Felske, A., Wolterink, A., Lis, R. V. \& Akkermans, A. D. L. (1998). Phylogeny of the main bacterial 16S rRNA sequences in Drentse a grassland soils (the Netherlands). Applied and Environmental Microbiology, 64, 871-879. doi:10.1016/S0038-0717(03)00124-X

Glavin, D. P., Cleaves, H. J., Schubert, M., Aubrey, A. \& Bada, J. L. (2004). New method for estimating bacterial cell abundances in natural samples by use of sublimation. Applied and Environmental Microbiology, 70: 5923-5928. doi:10.1128/ AEM.70.10.5923-5928.2004

Gould, G. W. \& Measures, J. C. (1977). Water relations in single cells. Philosophical Transactions of the Royal Society (B), 278, 151-166. doi: 10.1098/ rstb.1977.0035

Gupta, S. \& Sharma, R. (2011). Isolation, characterization and growth kinetics of chaotrope induced water stress tolerant bacteria from soils of Thar Desert. The International Journal of Applied Biology and Pharmaceutical Technology, 2(4), 163-171. Retrieved from http://www.ijabpt.com/pdf/32025-Shikha $\% 20$ Gupta[1].pdf

Hallsworth, J. E., Prior, B. A., Nomura, Y., Iwahara, M. \& Timmis, K. N. (2003). Compatible solutes protect against chaotrope (ethanol)-induced, nonosmotic water stress. Applied and Environmental Microbiology, 69: 7032-7034. doi:10.1128/ AEM.69.12.7032-7034.2003

Harris, R. F. (1981). Effect of water potential on microbial growth and activity. In Parr, J. F., Gardner, W. R. \& Elliott, L. F. (Ed.), Water potential relations in soil microbiology (pp. 23-95). Madison: Soil Science Society of America.

Herry, S. E., Hichem, N. \& Noureddine, B. (2009). Morphological characteristics and phylogenetic analyses of unusual morphospecies of Microcystis novacekii forming bloom in the Cheffia Dam (Algeria). Journal of Limnology, 68(2), 242-250. doi: 10.4081/ jlimnol.2009.242

Jadhav, G. G., Salunkhe, D. S., Nerkar, D. P. \& Bhadekar, R. K. (2010). Isolation and characterization of salt-tolerant nitrogen-fixing microorganisms from food. EurAsian Journal of BioSciences, 4(5), 33-40. doi:10.5053/ejobios.2010.4.0.5

Kandler, O. \& Weiss, N. (1986). Genus Lactobacillus. In P. H. A. Sneath, N. S. Mair, M. E. Sharpe, J. G. Holt (Ed.), Bergey's Manual of Systematic Bacteriology (Vol. 2, pp. 1209-1234). Baltimore: Williams and Wilkins.
Kempf, B. \& Bremer, E. (1998). Uptake and synthesis of compatible solutes as microbial stress responses to high-osmolality environments. Archives of Microbiology, 170, 319-330. doi:10.1007/s002030050649

Khathuria, N. (1998). Rhizosphere microbiology of desert. M.Sc. dissertation, Maharshi Dayanand Saraswati University, Ajmer (India).

Khyami-Horani, H. (1996). Thermotolerant strain of Bacillus licheniformis producing lipase. World Journal of Microbiology and Biotechnology, 12, 399-401. doi:10.1007/BF00340219

Kieft, T. L. (2002). Hot desert soil communities. In G. Bitton, (Ed.), Encyclopedia of Environmental Microbiology (pp. 1576-1586). New York: John Wiley.

Klotz, M. G. \& Loewen, P. C. (2003). The molecular evolution of catalatic hydroperoxidases: evidence for multiple lateral transfer of genes between prokaryota and from bacteria into eukaryota. Molecular Biology and Evolution, 20, 1098-1112. doi:10.1093/molbev/ msg129

Krieg, R. N. \& Holt, J. G. (1984). Bergey's manual of systematic Bacteriology volume 1 (pp. 308-429). Baltimore: Williams and Wilkins Company.

Kushner, D. J. (Ed.). (1998). Life in high salt and solute concentrations. Microbial life in extreme environments. London: Academic Press.

Lorenz, M. G. \& Wackernagel, W. (1994). Bacterial gene transfer by natural genetic transformation in the environment. Microbiological Reviews, 58, 563602. Retrieved from http://mmbr.highwire.org/content/58/3/563.full.pdf + html

Nahrstedt, H., Waldeck, J., Grone, M., Eichstadt, R., Feesche, J. \& Meinhardt, F. (2005). Strain development in Bacillus licheniformis: construction of biologically contained mutants deficient in sporulation and DNA repair. Journal of Biotechnology, 119, 245-254. doi:10.1016/j.jbiotec.2005.04.00

Nielsen, K. M., Van Weerelt, M. D. M., Berg, T. N., Bones, A. M., Hagler A. N. \& Van Elsas, J. D. (1997). Natural transformation and availability of transforming DNA to Acinetobacter calcoaceticus in soil microcosms. Applied and Environmental Microbiology, 63, 1945-1952. Retrieved from http://aem.asm.org/ content/63/5/1945.abstract

Otsuka, S., Suda S. Li, Matsumoto, R. \& Watanabe, M. M. (2000). Morphological variability of colonies of Microcystis morphospecies in culture. Journal of General and Applied Microbiology, 46, 39-50. doi:10.2323/jgam.46.39

Pangallo, D., Drahovská, H., Harichová, J., Karelová, E., Chovanová, K., Aradská, J. \& Timko, J. (2009). Evaluation of different PCR-based approaches for the identification and typing of environmental 
Enterococci. Antonie Van Leeuwenhoek, 93, 193-203. doi: 10.1007/s10482-007-9193-Z

Pomposiello, P. J. \& Demple, B. (2002). Global adjustment of microbial physiology during free radical stress. Advances in Microbial Physiology, 46, 319-341. doi: 10.1016/S0065-2911(02)46007-9

Rainey, F. A., Ray, K., Ferreira, M., Gatz, B. Z., Nobre, M. F., Bagaley, D. \& Andda Costa, M. S. (2005). Extensive diversity of ionizing radiation-resistant bacteria recovered from a Sonoran Desert soil and the description of nine new species of the genus Deinococcus from a single soil sample. Applied and Environmental Microbiology, 71, 5225-5235. doi:10.1128/AEM.71.9.5225-5235.2005

Rao, A. V. \& Venkateswarlu, B. (1983). Microbial ecology of the soils of Indian desert. Agriculture, Ecosystems and Environment, 10, 361-369. doi: 10.1016/0167-8809(83)90087-7
Rohlf, F. J. (1998). NTSYS-pc Numerical taxonomy and multivariate analysis system. version 2.02e. EXETER Software Setauket. Retrieved from http://www. exetersoftware.com/cat/ntsyspc/ntsyspc.html

Sambrook, J. \& Russell, D. W. (2001). Molecular cloning: a laboratory manual. New York: Cold Spring Harbor Laboratory Press.

Venkateswarulu, B. \& Rao, A. V. (1981). Distribution of microorganisms in stabilised and unstabilised sand dunes of Indian desert. Journal of Arid Environments, 4, 203-208.

Zhou, J., Xia, B., Huang, H., Treves, D. S., Hauser, L. J., Mural \& Tiedje, J. M. (2003). Bacterial phylogenetic diversity and a novel candidate division of two humid region, sandy surface soils. Soil Biology and Biochemistry, 35, 915-924. doi:10.1016/ S0038-0717(03)00124-X 